\title{
Vitamin $D$ in the prevention and treatment of periodontal diseases: an integrative review
}

\author{
Vitamina D na prevenção e tratamento de doenças periodontais: uma revisão integrativa \\ La vitamina D en la prevención y el tratamiento de las enfermedades periodontales: una revisión \\ integradora
}

Received: 09/17/2021 | Reviewed: 09/26/2021 | Accept: 10/01/2021| Published: 10/03/2021

\author{
Marlon Mezadri Layber \\ ORCID: https://orcid.org/0000-0002-9782-5740 \\ Universidade Potiguar, Brazil \\ E-mail: marlon_mezadri@uol.com.br \\ Alyne Barreto Mesquita de Goés \\ ORCID: https://orcid.org/0000-0001-5187-6174 \\ Universidade Potiguar, Brazil \\ E-mail:alynebarreto2@hotmail.com \\ Camila Vilar de Oliveira Villarim \\ ORCID: https://orcid.org/0000-0002-3173-7932 \\ Universidade Potiguar, Brazil \\ E-mail:camilavillarim@gmail.com \\ Diego Maia Diógenes Rabelo Caldas \\ ORCID: https://orcid.org/0000-0002-5163-8237 \\ Universidade Potiguar, Brazil \\ E-mail: diego_dmaia@hotmail.com \\ Irami Araújo-Neto \\ ORCID: https://orcid.org/0000-0003-3360-2991 \\ Universidade Potiguar, Brazil \\ E-mail:irami.neto@uol.com.br \\ Laura Cristina Costa e Silva \\ ORCID: https://orcid.org/0000-0002-2591-5085 \\ Universidade Potiguar, Brazil \\ E-mail:lauracristina_99@hotmail.com \\ Amália Cinthia Meneses Rêgo \\ ORCID: https://orcid.org/0000-0002-0575-3752 \\ Universidade Potiguar, Brazil \\ E-mail:amalirego@unp.br \\ Irami Araújo-Filho \\ ORCID: https://orcid.org/0000-0003-2471-7447 \\ Universidade Potiguar, Brazil \\ E-mail:irami.filho@uol.com.br
}

\begin{abstract}
Introduction: Vitamin D is synthesized from 7-dehydrocholesterol during a photochemical reaction, under the effect of ultraviolet radiation on the skin, obtained from food. It is hydroxylated in the liver to 25-hydroxyvitamin D3 $(25(\mathrm{OH}) \mathrm{D} 3)$. It is an active metabolite, which maintains the balance of calcium and phosphorus concentration in the blood, in addition to helping bone remodeling. Vitamin D deficiency promotes rickets in children and osteoporosis in adults, with a risk of bone fracture. Vitamin $\mathrm{D}$ acts in the pathogenesis of periodontal diseases via immunomodulation, increases mineral density and reduces bone resorption, which is important in combating agents that cause periodontal diseases. Objectives: Evaluate the importance of vitamin D in the prevention and treatment of periodontal diseases. Methods: A search was carried out in the PubMed/Medline, Scopus, Scielo, Embase, Web of Science and Google Scholar databases on scientifically proven evidence on the subject. Results: The present review demonstrated the importance of vitamin $\mathrm{D}$ in the prevention and treatment of periodontitis and the consequences of its deficiency on the oral health of patients. Conclusion: Vitamin D plays an important role in oral homeostasis and vitamin deficiency results in periodontal disease.
\end{abstract}

Keywords: Calcitriol receptors; Oral pathology; Pathologic bone demineralization; Periodontal diseases; Vitamin D.

\section{Resumo}

Introdução: A vitamina D é sintetizada a partir do 7-dehidrocolesterol durante reação fotoquímica, sob efeito da radiação ultravioleta na pele, obtida de alimentos. É hidroxilada no fígado em 25-hidroxivitamina D3 (25(OH)D3). Trata-se de metabólito ativo, que mantém o equilíbrio de cálcio e a concentração de fósforo no sangue, além de 
auxiliar a remodelação óssea. A deficiência de vitamina D promove raquitismo em crianças e osteoporose em adultos, com risco de fratura óssea. A vitamina $\mathrm{D}$ atua na patogênese das doenças periodontais via imunomodulação, aumenta a densidade mineral e reduz a reabsorção óssea, importante no combate contra agentes causadores de doenças periodontais. Objetivos: Avaliar a importância da vitamina D na prevenção e no tratamento das doenças periodontais. Métodos: Realizou-se pesquisa nas bases de dados PubMed/Medline, Scopus, Scielo, Embase, Web of Science e Google Scholar sobre o que há de evidências cientificamente comprovadas sobre o tema. Resultados: A presente revisão demonstrou a importância da vitamina D na prevenção e tratamento da periodontite e as consequências da deficiência desta na saúde oral dos pacientes. Conclusão: A vitamina D desempenha um papel importante na homeostase oral e o déficit vitamínico resulta em doença periodontal.

Palavras-chave: Doenças periodontais; Desmineralização patológica óssea; Patologia oral; Receptores de calcitriol; Vitamina D.

\section{Resumen}

Introducción: La vitamina D se sintetiza a partir del 7-dehidrocolesterol durante una reacción fotoquímica, bajo el efecto de la radiación ultravioleta en la piel, obtenida de los alimentos. Se hidroxila en el hígado a 25-hidroxivitamina D3 (25 (OH) D3). Es un metabolito activo, que mantiene el equilibrio de la concentración de calcio y fósforo en la sangre, además de ayudar a la remodelación ósea. La deficiencia de vitamina D promueve el raquitismo en los niños y la osteoporosis en los adultos, con riesgo de fractura ósea. La vitamina D actúa en la patogenia de las enfermedades periodontales a través de la inmunomodulación, aumenta la densidad mineral y reduce la resorción ósea, lo que es importante en la lucha contra los agentes causantes de las enfermedades periodontales. Objetivos: Evaluar la importancia de la vitamina D en la prevención y el tratamiento de las enfermedades periodontales. Métodos: Se realizó una búsqueda en las bases de datos PubMed / Medline, Scopus, Scielo, Embase, Web of Science y Google Scholar sobre evidencia científicamente probada sobre el tema. Resultados: Esta revisión demostró la importancia de la vitamina $\mathrm{D}$ en la prevención y el tratamiento de la periodontitis y las consecuencias de su deficiencia en la salud bucal de los pacientes. Conclusión: La vitamina D juega un papel importante en la homeostasis oral y la deficiencia de vitamina da como resultado la enfermedad periodontal.

Palabras clave: Enfermedades periodontales; Desmineralización ósea patológica; Patología bucal; Receptores de calcitriol; Vitamina D.

\section{Introduction}

Vitamin D is present in several organic physiological processes, such as growth, cell differentiation, immunity, bone and calcium metabolism, in addition to cardiovascular function. (Nagpal et al., 2005).

Ultraviolet irradiation on skin exposed to sunlight induces the photochemical reaction of 7-dehydrocholesterol to produce vitamin D3 (cholecalciferol). This is hydroxylated at position 25 by the liver enzymes D3-hydroxylase, sterol 27hydroxylase (CYP27A1) and D 25-hydroxylase (CYP2R1), generating 25-hydroxyvitamin D3 (25-hydroxycholecalciferol), the main form of vitamin D in the bloodstream (Nagpal et al., 2005; Makishima et al., 2005; Jones G, 2008).

The 25-hydroxyvitamin D3 is hydroxylated at position 1A by 25-hydroxyvitamin D 1 $\alpha$-hydroxylase (CYP27B1). This reaction, carried out in the kidneys, is strictly regulated for the production of the active metabolite 1,25-dihydroxy vitamin D3 (1,25(OH)2D3), 1,25-dihydroxycholecalciferol or calcitriol (Makishima et al., 2005; Jones G, 2008).

Both vitamin D2 (ergocalciferol), present in vegetables, and vitamin D3 undergo the same activation process, which involves 25-hydroxylase in the liver and, later, $1 \alpha$-hydroxylase in the kidneys, being converted into active metabolites, 1 , 25(OH)2D2 and 1.25(OH)2D3 (Jones, 2008; Cheng et al., 2003).

These molecules bind to the vitamin D nuclear receptor (VDR), expressed in the target organs of calcium homeostasis, which are the intestine, bones, kidneys and parathyroid glands. Epidemiological data and studies performed with VDR-null mice highlighted the role of vitamin D in preventing cancer, infection and cardiovascular disease (Haussler et al., 1998; Giovannucci et al., 2006).

$1,25(\mathrm{OH}) 2 \mathrm{D}$ regulates more than 200 genes involved in the production of renin in the kidneys, insulin in the pancreas, cathelicidin in macrophages, cytokine release, production, growth and proliferation of vascular and smooth muscle cells. Furthermore, vitamin D also exerts immunomodulatory and anti-inflammatory effects, capable of suppressing proinflammatory cytokines (Nagpal et al., 2005; Makishima et al., 2005; Haussler et al., 1998; Giovannucci et al., 2006; Wang et 
al., 2008; Holick 2007).

Vitamin D and chronic periodontitis are closely related to bone metabolism, inflammation and immunity (Wang et al., 2008; Holick 2007). Genetic polymorphisms cause changes in VDR genes, which contribute to the development of periodontitis and alter the four specific genetic loci: Fok-1, Bsm-I, Apa-I and Taq-I on chromosome 12q12-14 (Holick 2009; Adams et al., 2010; Wang et al., 2012; Nibali et al., 2017; Chen et al., 2012).

Fok-I polymorphisms are risk factors for acute periodontitis, while the Bsm-I and Apa-I loci were not associated with disease susceptibility. Changes in the VDR and 1,25(OH)2D-mediated signaling pathways, facing periodontitis, are undefined (Holick 2009; Chen et al., 2012; Sun et al., 2002; Tachi et al., 2003; Brett et al., 2005; Gunes et al., 2008).

Vitamin D metabolites, 25-hydroxyvitamin D (25(OH)D), 25-hydroxyvitamin D3 (25(OH)D3) and calcitriol, in the active form (1,25(OH)D2D), have different half-ranges life ranging from 2-3 weeks, 15 days and 4-21h, respectively (Adams et al., 2010).

The VDR binds to calcitriol, the active form of vitamin D (1,25(OH)D2D) and 25(OH)D3, the inactive metabolite, also has an affinity. Calcitriol is not considered an adequate biomarker, with vitamin $\mathrm{D}(25(\mathrm{OH}) \mathrm{D})$ being clinically relevant (Wang et al., 2012).

Vitamin D can modulate the inflammatory effects of oral pathogens that contribute to periodontitis, therefore, there is a correlation between low serum levels of vitamin D and periodontitis (Jones G, 2008; Holick 2009; Nibali et al., 2008; Laine et al., 2012; Martelli et al., 2014; Zerwekh 2008; Lou et al., 2010; Huet et al., 2015).

In this sense, this review aimed to address the importance of vitamin D in the pathogenesis of periodontal diseases, since the increase in cases of periodontitis is of interest to the scientific community, especially among health professionals working in the area.

\section{Methods}

The search was carried out in search of current evidence from an integrative literature review about the relationship between Vitamin D and treatment of periodontal diseases. The databases PubMed/Medline, Scopus, Scielo, Embase, Web of Science, and Google Scholar databases, known as gray literature. Around 78 studies related to periodontitis and vitamin D were selected through the combination of indexes present in the MeSH Platform (Medical Subject Headings) PubMed/Medline: Vitamin D, Calcitriol Receptors, Periodontal Diseases, Metabolic Bone Disease, Pathologic Bone Demineralization, Oral and Maxillofacial Pathology. However, 22 studies that addressed other topics, or did not have the full text related to periodontitis and vitamin D or at least one keyword in the title or abstract, were excluded from the research. Relevants and scientifically validated studies carried out in humans, in a cohort, systematic review, case-control, crosssectional, case series, and randomized clinical trials modalities were included. The entire process involved the following guiding question: "What is scientific evidence about the role of vitamin $D$ in the prevention and treatment of periodontitis, an oral disease that affects millions of people around the world?". The analysis, review, and selection of articles were performed by pairs, blindly and separately, based on the reading of the title and abstract, with a third reviewer in case of disagreement. (Pereira et al., 2018).

\section{Results and Discussion}

Vitamin D is effective in skeletal and mineral homeostasis, maintains adequate levels of extracellular calcium and skeletal integrity. Similarly, the NF-kB nuclear factor activating receptor-ligand (RANK-L) and its antagonist, osteoprotegerin (OPG), produced by osteoblasts and other cells, are relevant regulators of bone remodeling (De Brito et al., 2004).

OPG acts as a soluble at the RANK-L receptor, inhibits the interaction between RANK-RANK-L and the maturation 
of osteoclast progenitor cells. The relationship of RANK-L to OPG in the osteoclast precursor microenvironment can determine the formation of mature osteoclasts (Huet et al., 2015).

The gene promoting the RANK-L structure contains vitamin D and glucocorticoid response elements. Studies indicate that vitamin D stimulates the expression of RANK-L in osteoblasts and bone marrow cells (Lacey et al., 1998).

Vitamin D promotes a reduction in the expression of OPG, increased expression of RANK-L, which favors the differentiation and activation of osteoclasts, and increased bone resorption. (Lou et al., 2010; Huet et al., 2015; De Brito et al., 2004) It also has anabolic effects on osteoblasts, stimulates osteopontin and alkaline phosphatase (Kitazawa et al., 2003).

Vitamin D deficiency, whether due to low intake or endogenous generation, results in calcium imbalance, interrupts mineralization, and compromises bone structure, in addition to causing rickets in children, osteoporosis in adults, and increasing the risk of fractures (Laine et al., 2012; Martelli et al., 2014; Zerwekh 2008).

The ideal concentration of $25(\mathrm{OH}) \mathrm{D} 3$ recommended in blood plasma should be greater than $80 \mathrm{nmol} / \mathrm{L}$ and, in periodontal tissue, $90-100 \mathrm{nmol} / \mathrm{L}$. Low concentrations are associated with the progression of periodontal disease and tooth loss (Stein et al., 2011; Hildebolt 2005; Van der et al., 2011).

The mandibular bone is one of the four tissues that make up the periodontium. In osteoporosis, mineral density is reduced in the jaw, which favors the resorption of the alveolar crest and tooth loss in the upper and lower arches (Amano et al., 2009; Stewart et al., 2012).

Al Habashneh et al. observed in 400 elderly women, low bone mineral density, progressive chronic periodontitis, and increased resorption of the alveolar process. The study revealed that patients who ingested vitamin D suffered less from chronic periodontitis when compared to the control group (Al Habashneh et al., 2012).

The increase in the levels of inflammatory cytokines favors bone resorption in the skeleton and the jaw of individuals with low systemic mineral density. Periodontal infection stimulates osteoclast activity and bone resorption (Wactawski et al., 2005).

Jabbar et al. in a case-control study included 185 postmenopausal women with osteoporosis and compared it with 185 healthy women of the same age, where the correlation between cytokines and the concentration in the blood plasma of 25hydroxyvitamins D were compared. In women with osteoporosis, the ratio was significantly lower compared to the control group (66.62 nmol/L - $97.21 \mathrm{nmol} / \mathrm{L}$, respectively), while the number of cytokines, RANK-L and osteoprotegerin (OPG) were significantly bigger (Jabbar et al., 2011).

Wactawski-Wende et al. argue that due to its ability to increase bone mineral density and reduce resorption, vitamin D3 can be supplemented to prevent and treat periodontitis in postmenopausal women, especially when ingested daily in doses above 800-1,000 UI (Wactawski et al., 2005; Garcia et al., 2011).

Furthermore, dietary supplementation can improve periodontal health, increase jaw mineral density and inhibit alveolar bone resorption. In addition, vitamin D acts as an anti-inflammatory agent, as it modulates the expression of inflammatory cytokines, stimulating monocytes/macrophages (Andresen et al., 2006; Cozzolino et al., 2001; Zittermann 2003; Holick 2004).

Analysis of restriction fragment length polymorphism (RFLP) of the VDR gene showed an association of vitamin D deficiency with hyperparathyroidism in renal failure, osteoporosis, cancer, nephrolithiasis, diabetes and periodontal disease (Garcia et al., 2011).

Located between exons 8 and 9, the RFLPs Bsml, Tru9I, TaqI, EcoRV and ApaI act on mRNA stability. RFLP Folk creates a start codon in exon 2, resulting in an alternative start site in conjunction with RFLP Taql and periodontitis. A rare and aggressive association of the $\mathrm{T}$ allele and periodontitis was observed, located in Caucasian individuals (Holick 2004; Vladivielso et al., 2006). 
Thymine phenotype, allele genotype (TT) and T allele are associated with periodontitis in Japanese and Caucasian individuals, while TT genotype and $\mathrm{T}$ allele are related to the onset of aggressive periodontitis in Chinese individuals (Chen $e t$ al., 2012; Sun et al., 2002; Tachi et al., 2003).

The TT genotype and the T allele are associated with decreases in bone mineral density and a higher incidence of osteoporosis, suggesting that RFLP TaqI is related to immune function and bone metabolism. Ethnic differences and different mechanisms of acute and chronic periodontitis may influence the results of the RFLP TaqI analysis (Sun et al., 2002).

In combination with other RFLPs, RFLP BsmI is related to aggressive periodontitis and chronic periodontitis diagnosed in Koreans. Reports of RFLPs ApaI, BsmI and FokI correspond to an increased risk of severe chronic periodontitis in Japanese men. These RFLPs are associated with bone mineral disease, while the RFLPs TaqI and FokI are related to an increased risk of prostate and breast cancer (Lacey et al., 1998; Hennig et al., 1999).

Liu et al. found that during the inflammatory process, fibroblasts in the dental pulp and periodontal cells produce 25hydroxylase, which stimulates the production of $25(\mathrm{OH}) \mathrm{D} 3$. Pathological microorganisms activate cell membrane receptors, 1ß-hydroxylase synthesis is initiated, forming 1,25(OH)D3 from 25(OH)D3 (Liu et al., 2012).

The generated molecule binds to the VDR of immune and epithelial cells and participates in the epithelial defense mechanism against the pathogen. 1,25(OH)D3 activates the synthesis of proteins necessary for the desmosomal junction of epithelial cells. The epithelium connects to the tooth through loose joints and thus creates favorable conditions for bacterial invasion into the dental plaque. Initially, this process causes inflammation of the periodontal tissue and, as it progresses, it causes resorption and progressive tooth loss (Schwalfenberg 2011; Bikle 2008).

$1,25(\mathrm{OH}) \mathrm{D} 3$ regulates the nonspecific immune response, activates hydrogen peroxide secretion in monocytes, stimulates the synthesis of antimicrobial peptides, b-defensin and cathelicidin LL-37 (Liu et al., 2012).

Cathelicidin LL-37 plays a role in chemotaxis, cytokine production, cell reproduction, vascular permeability, wound healing, and bacterial endotoxin neutralization (Schwalfenberg 2011; Bikle 2008).

McMahon et al. evaluated human gingival cell cultures and the effect of vitamin D on the expression of the immune system. After adding the gingival cell cultures to $1,25(\mathrm{OH}) \mathrm{D} 3$, an increase in cathelicidin secretion, LL-37, and an antimicrobial effect against Actinobacillus actinomycetemcomitans lasting 24 hours were observed (McMahon et al., 2011).

Vitamin D suppresses T lymphocyte proliferation, immunoglobulin secretion, transformation of B lymphocytes into plasma cells, inhibits the unwanted process and protects the body from excessive systemic inflammatory response, inhibiting the secretion of IL-1, IL-6, IL-8 and TNFa (Stein et al., 2011; Liu et al., 2012).

During bacterial invasion, these cytokines are released in the pathogenesis of periodontitis, causing lymphocyte infiltration, bone resorption, deterioration of the extracellular matrix (Schwalfenberg 2011).

Tang et al. analyzed cell cultures of human periodontal tissue in order to identify the anti-inflammatory effect of vitamin D. Lower levels of IL-8 were found in cultures containing Porphyromonas gingivalis and 1,25(OH)D3 compared to the control group (Tang et al., 2013).

The anti-inflammatory functions of vitamin D were demonstrated by Teles et al. who observed higher serum concentrations of vitamin D, and lower concentrations of IL-6, leptin and adiponectin, which regulate the immune response. Elevated leptin means the presence of an infectious process and inflammation ( $\mathrm{T}$ lymphocyte proliferation and activation, cytokine production), while adiponectin production suppresses cytokine production and activity (Teles et al., 2012).

In acute periodontal inflammation, the concentration of $25(\mathrm{OH}) \mathrm{D} 3$ increases due to the 25-hydroxylase activity of periodontal cells. In chronic inflammation, in turn, this concentration decreases. Due to the production of this enzyme in aggressive periodontitis, the concentration of $25(\mathrm{OH}) \mathrm{D} 3$ in periodontal pockets is 300 times higher than in blood plasma (Liu et al., 2012; Liu et al., 2009). 
Zhang et al. highlight that in cases of aggressive periodontitis there is an increase in the concentration of IL-6 and $25(\mathrm{OH}) \mathrm{D} 3$, leukocytes and neutrophils. Low concentration of $25(\mathrm{OH}) \mathrm{D} 3$ in blood plasma indicates vitamin D deficiency, decompensated immune reactions and progression of periodontal disease (Zhang et al., 2013; Millen et al., 2013).

In order to investigate the action of vitamin D on gingival fibroblasts (hGFs) and periodontal ligament cells (hPDLCs) in periodontal immune defense. analyzed primary cultures of hGFs and hPDLCs, stimulated with 1,25-dihydroxy vitamin D3 and 25-hydroxy vitamin D3, with or without lipopolysaccharide from Porphyromonas gingivalis (Zhanyi et al., 2018).

As a result, the researchers observed that, in hGFs and hPDLCs, 25-hydroxy vitamin D3 and 1,25-dihydroxyvitamin D3 induced hCAP-18/LL-37 expression, which was additionally elevated by the presence of lipopolysaccharide from Porphyromonas gingivalis. The conclusion of the study is that the vitamin D pathway can be found in hGFs and hPDLCs, playing an important role in immune defense in periodontal soft tissues (Zhanyi et al., 2018).

Periodontitis is closely related to other glycemic abnormalities. Aiming to evaluate the joint effects of 25hydroxyvitamin D3 and 25-hydroxyvitamin D total in periodontitis, Zuk et al. used the homeostasis assessment model (HOMA-IR) for insulin resistance, pre-diabetes and type 2 diabetes. Based on the 2009-2010 data from the National Health and Nutrition Examination Survey (NHANES), the sample was restricted to adults over 30 years old, who have an oral health examination and measured levels of vitamin D, fasting glucose and insulin. The analytical sample included individuals diagnosed $(\mathrm{n}=1631)$ or not $(\mathrm{n}=1369)$ with type 2 diabetes (Zuk et al., 2018).

Using research logistic multivariate regression analysis, the researchers examined the following joint effects: vitamin $\mathrm{D}$ insufficiency $(<50 \mathrm{nmol} / \mathrm{L})$ and moderate to severe periodontitis (VD+/PD+); vitamin D insufficiency and mild to none periodontitis (VD+/PD-); and vitamin D sufficiency ( $>50 \mathrm{nmol} / \mathrm{L})$ and periodontitis (VD- / PD + ). Comparisons between these three groups with the control groups (VD - PD-) were drawn, and the results showed that the joint effects of 25hydroxyvitamin D3 and total 25-hydroxyvitamin D insufficiency with periodontitis (VD+ / PD+) were associated with diabetes significantly. The joint effects of vitamin D insufficiency and periodontitis, however, were attenuated for HOMA-IR, whereas prediabetes was not associated with joint effects. The conclusion reveals that the joint effects of vitamin D and periodontitis apparently differ for HOMA-IR, pre-diabetes and diabetes (Zuk et al., 2018).

Although there is still no consensus on optimizing the serum $25(\mathrm{OH}) \mathrm{D}$ level, generally are considered deficient 25(OH)D levels <20ng/mL of vitamin D, while levels of 21-29ng/mL are not sufficient (Tang et al., 2013; Tele et al., 2012; Liu et al., 2009).

Vitamin D deficiency has become an epidemic, with a billion people experiencing a deficit or insufficiency. Evidence reveals that more than $70 \%$ of individuals with a mean age of 12 years have serum $25(\mathrm{OH}) \mathrm{D}$ levels below $32 \mathrm{ng} / \mathrm{mL}$. $25(\mathrm{OH}) \mathrm{D}$ deficiency is the result of lack of sun exposure or inadequate nutrition, being prevalent in women, the elderly, and ethnic minorities (Zhanyi et al., 2018; Zuk et al., 2018; Chen et al., 2007).

Traditionally, the vitamin D requirement is obtained during sun exposure up to $95 \%$, through the synthesis in the skin, with the remainder ingested from food sources. The US government recommends a daily oral intake of vitamin D equivalent to $200 \mathrm{IU}$ for individuals aged 50 and over, $400 \mathrm{IU}$ for persons aged 50 to 70 years, and 600 IU for those over 70 years of age (Zuk et al., 2018).

The best sources of vitamin D are sunlight (about 3,000 IU vitamin D3 / 5-10 minutes from midday, with half of the arms or legs exposed for clear skin) or 50,000 oral supplements IU every 15 days. Among foods, oily fish has the highest vitamin D3 content, ranging from 100-1,000 IU, while vitamin D-enriched milk or orange juice contains up to $100 \mathrm{IU}$ per serving (Holick, 2007).

As a general rule, $100 \mathrm{IU}$ of vitamin D daily increases the $25(\mathrm{OH}) \mathrm{D}$ level by about $1 \mathrm{ng} / \mathrm{mL}$. Dietary supplements of vitamins D2 and D3 contain 400-5,000 IU/capsule (Chen et al., 2007). 
Vitamin D deficiency treatment should start with 50,000 IU vitamin D2 or D3 weekly for a period of 8 to 12 weeks. At the end of this phase, maintenance therapy can follow as 50,000 IU vitamin D2 or D3 every two weeks; 1,000-2,000 IU vitamin D3/day; and exposure to sunlight for 5-10 minutes for Caucasians (longer time needed for people with increased skin pigmentation) between 10 am and 3 pm (spring, summer, and fall) (Heaney et al., 2003).

Regarding periodontitis, Bashutski et al. published the results of a long-term clinical study that evaluated the correlation between the amount of vitamin D in blood plasma and periodontal surgery. The researchers found that participants with vitamin D deficiency had a lower level of tissue attachment and probing depth change after periodontal surgery. Thereby, to improve postoperative outcomes, it is advisable to examine the vitamin D level in patients before treatment and avoid vitamin D deficiency through supplementation (Bashutski et al., 2011).

Alshouibi et al. observed that individuals who received more than 800 IU of vitamin D daily had a lower risk of developing severe forms of chronic periodontitis. While those who received 400 IU suffered from a more advanced level of alveolar bone resorption (Alshouibi et al., 2013).

Hiremath et al. used a random sampling of clinical trials to prove the anti-inflammatory action as an effect of vitamin D on the gums. The results showed that a dose of 500-2000 IU of vitamin D is safe and effective in gingival inflammation treatment (Hiremath et al., 2013).

Were obtained satisfactory results after three months, where individuals used doses of 2000IU or even higher of vitamin D. The consumption of higher doses led to a change in the concentration of 25(OH)D3 in blood plasma (Hiremath et al., 2013).

Without vitamin D consumption, the concentration increased by $0.87 \mathrm{nmol} / \mathrm{L}$. During the 500 IU consumption, the increase was $32.03 \mathrm{nmol} / \mathrm{L}$, while the $1000 \mathrm{IU}$ dose increased concentration of $42.12 \mathrm{nmol} / \mathrm{L}$; and $2000 \mathrm{UI}$ at $74.22 \mathrm{nmol} / \mathrm{L}$. The results demonstrate the effect of vitamin D on gingival inflammation and the dose of vitamin D needed to achieve this effect (Hiremath et al., 2013).

\section{Conclusion}

Historically, vitamin D is associated with maintaining healthy bone balance and calcium homeostasis. When deficient in the body, it results in calcium loss, mineralization interruption, and bone structure impairment. In children, it most commonly causes rickets and, in adults, it increases the risk of fractures. When adequate quantity, it prevents cardiovascular and neoplastic diseases, as well as having an immunomodulatory action.

The recommended concentration of $25(\mathrm{OH}) \mathrm{D} 3$ in blood plasma should be higher than $80 \mathrm{nmol} / \mathrm{L}$, while in periodontal tissue, the ideal is $90-100 \mathrm{nmol} / \mathrm{L}$.

Studies on the subject establish a significant relationship between periodontal health and vitamin D and calcium intake, its supplementation being able to improve periodontal health, increasing the bone mineral density of the jaw, and inhibiting alveolar bone resorption.

The vitamin D plays a significant role in oral health. Continuing research with vitamin D is necessary and relevant not only for the discoveries in combating periodontitis but through the benefits in preventing diseases linked to vitamin deficiency due to its direct effect on metabolism and anti-inflammatory properties.

Finally, in a multidisciplinary ideology and thinking about the future, it is important to carry out robust randomized clinical trials in the search for a better and better understanding of the relationship between vitamin $\mathrm{D}$ and periodontal diseases. In addition, it is essential to establish guidelines following the scientific literature, without the intention of avoiding sudden changes in effective therapeutic follow-up strategies. 


\section{References}

Adams, J. S., \& Hewison, M. (2010). Update in vitamin D. J Clin Endocrinol Metab. 95:471-478.

Al Habashneh, R., Alchalabi, H., Khader, Y. S., Hazza'a, A. M., Odat, Z., \& Johnson, G. K. (2010). Association between periodontal disease and osteoporosis in postmenopausal women in Jordan. J. Periodontol. 81:1613-1621.

Alshouibi, E. N., Kaye, E. K., Cabral, H. J., Leone, C. W., \& Garcia, R. I. (2013). Vitamin D and periodontal health in older men. J. Dent. Res. 92:689-693.

Amano, Y.,Komiyama, K., \& Makishima, M. (2009). Vitamin D and periodontal disease. J. Oral Sci. 51:11-20.

Andresen, C., Olson, E., Nduaka, C., Pero, R., \& Bagi, C. M. (2006). Action of calciotropic hormones on bone metabolism - Role of Vitamin D3 in bone remodeling events. Am J Immunol. 2:40-51.

Bashutski, J. D., Eber, R. M., Kinney, J. S., \& Benavides, A. L. (2011). The impact of vitamin D status on periodontal surgery outcomes. J. Dent. Res. 90:1007-1012.

Bikle, D. D. (2008). Vitamin D and the immune system: Role in protection against bacterial infection. Curr. Opin. Nephrol. Hypertens. 17:348-352.

Brett, P. M., Zygogianni, P., \& Griffiths, G. S. (2005). Functional gene polymorphisms in aggressive and chronic periodontitis. J Dent Res. 84:1149-1153.

Chen, L. L., Li, H., \& Zhang, P. P. (2012). Association between vitamin D receptor polymorphisms and periodontitis: a meta-analysis. J Periodontol. 83:1095103.

Chen, T. C., Chimeh, F., Lu, Z., Mathieu, J., Person, K. S., \& Zhang, A. (2007). Factors that influence the cutaneous synthesis and dietary sources of vitamin D. Arch Biochem Biophys. 460:213-217.

Cheng, J. B., Motola, D. L., Mangelsdorf, D. J., \& Russell, D. W. (2003). De-orphanization of cytochrome P450 2R1:a microsomal vitamin D 25-hydroxylase. J Biol Chem. 278:38084-38093.

Garcia, M. N.; Hildebolt, C. F., Miley, D., Dixon, D. A., Couture, R. A., \& Spearie, C. L. A. (2011). One-year effects of vitamin D and calcium supplementation on chronic periodontitis. JPeriodontol. 82(1):25-32.

Giovannucci, E., Liu, Y., Rimm, E. B., Hollis, B. W., Fuchs, C. S., Stampfer, M. J., \& Willett, W. C. (2006). Prospective study of predictors of vitamin D status and câncer incidence and mortality in men. J Natl Cancer Inst. 98:451-459

Gunes, S., Sumer, A. P., \& Keles, G. C. (2008). Analysis of vitamin D receptor gene polymorphisms in patients with chronic periodontitis. Indian J Med Res. 127:58-64.

Haussler, M. R., Whitfield, G. K., Haussler, C. A., Hsieh, J. C., Thompson, P. D., Selznick, S. H., Dominguez, C. E., \& Jurutka, P. W. ( 1998) . The nuclear vitamin D receptor: biological and molecular regulatory properties revealed. J Bone Miner Res. 13:325-349.

Heaney, R. P., Davies, K. M., Chen, T. C., Holick, M. F., \& Barger-Lux, M. J. (2003). Human serum 25-hydroxycholecalciferol response to extended oral dosing with cholecalciferol. Am JClin Nutr. 77:204-10.

Hennig, B. J., Parkhill, J. M., Chapple, I. L., Heasman, P. A., \& Taylor, J. J. (1999). Association of a vitamin D receptor gene polymorphism with localized early-onset periodontal diseases. JPeriodontol. 70:1032-1038.

Hildebolt, C. F. (2005). Effect of vitamin D and calcium periodontitis. J. Periodontol. 76: 1576-1587.

Hiremath, V.P., Rao, C. B., Naiak, V., \& Prasad, K. V. (2013). Anti-inflammatory effect of vitamin D on gingivitis: A dose response randomized controlled trial. Indian J. Public Health. 57: 29-32.

Holick, M. F. (2007). Vitamin D deficiency. N Engl J Med. 357:266-281.

Holick, M. F. (2009). Vitamin D status: measurement, interpretation, and clinical application. Ann Epidemiol. 19:73-78.

Holick, M. F. (2004). Vitamin D: Importance in the prevention of cancers, type 1 diabetes, heart disease, and osteoporosis. Am J Clin Nutr. 79:362-71.

Huet, T., Laverny, G., \& Ciesielski, F. (2015). A vitamin D receptor selectively activated by gemini analogs reveals ligand dependent and independent effects. Cell Rep. 10:516-526.

Jabbar, S., Drury, J., Fordham, J., Datta, H. K., Francis, R. M., \& Tuck, S. P. (2011). Plasma vitamin D and cytokines in periodontal disease and postmenopausal osteoporosis. J. Periodontal Res. 46:97-104.

Jones, G. (2008). Pharmacokinetics of vitamin D toxicity. Am J Clin Nutr. 88:582-586.

Kitazawa, S., Kajimoto, K., \& Kondo T. (2001). Vitamin D3 supports osteoclastogenesis via functional parathyroid growth arrest by vitamin D and high calcium. Kidney Int. 60:2109-17.

Lacey, D. L., Timms, E., Tan, H. L., Kelley, M. J., Dunstan, C. R., \& Burgess, T. (1998). Osteoprotegerin ligand is a cytokine that regulates osteoclast differentiation and activation. Cell. 93:165-176.

Laine, M. L., Crielaard, W., \&Loos, B. G. (2012). Genetic susceptibility to periodontitis. Periodontol. 58:37-68.

Liu, K, Meng, H., \& Hou, J. (2012). Activity of 25-hydroxylase in human gingival fibroblasts and periodontal ligament cells. PLoS ONE. 7:e52053. 
Liu, K, Meng H, Tang X, Xu L, Zhang L, Chen Z, Shi D, Feng X \& Lu R. (2009). Elevated plasma calcifediol is associated with aggressive periodontitis. J. Periodontol. 80:1114-1120.

Lou Y. R, Molnár F \& Peräkylä M. (2010). 25-Hydroxyvitamin D(3) is an agonistic vitamin Dreceptor ligand. J Steroid Biochem Mol Biol. 118:162-170.

Makishima M., \& Yamada S. (2005). Targeting the vitamin D receptor: advances in drug discovery. Expert Opin Ther Pat. 15:1133-1145.

Martelli F. S, Martelli M, \& Rosati C. (2014). Vitamin D: relevance in dental practice. Clin Cases Miner Bone Metab. 11:15.

McMahon L, Schwartz K, Yilmaz O, Brown E, Ryan L. .K, \& Diamond G. (2011). Vitamin D-mediated induction of innate immunity in gingival epithelial cells. Infect. Immun. 79:2250-2256.

Millen A. E, Hovey K. M, LaMonte M. J, Swanson M, Andrews, C. .A \& Kluczynski M. A. (2013). Plasma 25-hydroxyvitamin D concentrations and periodontal disease in postmenopausal women. J. Periodontol. 84:1243-1256.

Nagpal S., \& Rathnachalam R. (2005). Noncalcemic actions of vitamin D receptor ligands. Endocr Rev. 26:662-687.

Nibali L, Di Iorio A., \& Tu Y. K. (2017). Host genetics role in the pathogenesis of periodontal disease and caries. J Clin Periodontol. $44(18)$ : S52-S78.

Nibali L, Parkar M., \& D'Aiuto F. (2008). Vitamin D receptor polymorphism (-1056 Taq-I) interacts with smoking for the presence and progression of periodontitis. J Clin Periodontol. 35:561-567.

Pereira, A. S., Shitsuka, D. M., Parreira, F. J. \& Shitsuka, R. (2018). Metodologia Da Pesquisa Científica (1st ed.). Santa Maria: Universidade Federal de Santa Maria.

Schwalfenberg G. K. (2011). A review of the critical role of vitamin D in the functioning of the immune system and the clinical implications of vitamin D deficiency. Mol. Nutr. Food Res. 55:96-108.

Stein S. H., \& Tipton D. A. (2011). Vitamin D and its impact on oral health - An update. J. Tenn. Dent. Assoc. 91:30-33.

Stewart S., \& Hanning R. (2012). Building osteoporosis prevention into dental practice. J. Can. Dent. Assoc. 78:c29.

Sun J. L, Meng H. X., \& Cao C. F. (2002). Relationship between vitamin D receptor gene polymorphism and periodontitis. J Periodontal Res. $37: 263-267$.

Tachi Y, Shimpuku H., \& Nosaka Y.(2003).Vitamin D receptor gene polymorphism is associated with chronic periodontitis. Life Sci. 73:3313-3321.

Tang X, Pan Y \& Zhao Y. (2013). Vitamin D inhibits the expression of interleukin-8 in human periodontal ligament cells stimulated with Porphyromonas gingivalis. Arch. Oral Biol. 58:397-407.

Teles F. R, Teles R. P, Martin L, Socransky S. S., \& Haffajee A. D. (2012). Relationships among interleukin-6, tumor necrosis factor-a, adipokines, vitamin D, and chronic periodontitis. J. Periodontol. 83:1183-1191.

Valdivielso J. M., \& Fernandez E. (2006). Vitamin D receptor polymorphisms and diseases. Clin Chim Acta. $371: 1-12$.

Van der Velden U, Kuzmanova D \& Chapple I. L. (2011). Micronutritional approaches to periodontal therapy. J. Clin. Periodontol. 38(11):142-158.

Wactawski-Wende J, Hausmann E, Hovey K, Trevisan M, Grossi S \& Genco R. J. (2005). The association between osteoporosis and alveolar crestal height in postmenopausal women. J. Periodontol. 76(11):2116-2124.

Wang. TJ, Pencina M. J, Booth S. L, Jacques P. F, Ingelsson E, Lanier K, Benjamin E. J, D’Agostino R. B, Wolf, M., \& Vasan R. S. (2008). Vitamin D deficiency and risk of cardiovascular disease. Circulation. 117:503-511.

Wang Y., Zhu J., \& DeLuca H. F. (2012). Where is the vitamin D receptor? Arch Biochem Biophys. 523:123-33.

Zerwekh, J. E. (2008). Blood biomarkers of vitamin D status. Am J Clin Nutr. 87:1087-1091.

Zhang X, Meng H, Sun X, Xu L, Zhang L., \& Shi D. (2013). Elevation of vitamin D-binding protein levels in the plasma of patients with generalized aggressive periodontitis. J. Periodontal Res. 48:74-79.

Zhanyi, G, Kaining, L., \& Huanxin, M. (2018). Preliminary investigation of the vitamin D pathway in periodontal connective tissue cells. 89(3):294-302.

Zittermann A. (2003). Vitamin D in preventive medicine: Are we ignoring the evidence? Br JNutr. 89:552-72.

Zuk A. M, Quiñonez C. R., \& Saarela O. (2018). Joint effects of serum vitamin D insufficiency and periodontitis on insulin resistance, pre-diabetes, and type 2 diabetes: results from the National Health and Nutrition Examination Survey (NHANES) 2009-2010. BMJ Open Diab Res Care. 6:e00535. 